\title{
EUROPEAN RESPONSES CRIMINALISING ONLINE SOLICITATION OF CHILDREN FOR SEXUAL PURPOSES
}

\author{
Libor KLIMEK \\ Associate Professor, Faculty of Law, \\ Matej Bel University in Banská Bystrica, Slovak Republic \\ E-mail: libor.klimek@umb.sk
}

\begin{abstract}
Online child grooming, solicitation of children for sexual purposes, is a threat at the international level. In 2000's several European States had already made online child grooming a criminal offence through national legislative measures. By the end of the decade, the majority of European States faced a new requirement to stipulate online child grooming as criminal offence at national level. For these purposes two crucial legislative instruments were introduced. First, the Council of Europe in 2007 adopted the Convention on the Protection of Children against Sexual Exploitation and Sexual Abuse. Second, the European Union in 2011 adopted the Directive 2011/93/EU on combating the sexual abuse and sexual exploitation of children and child pornography. The objective of this paper is the assessment of online child grooming and its criminalisation in Europe. It analyses relevant literature and legislation, national as well as European. The article will not focus on figures or the number of abused children. Rather, it is focused on common European approach towards the criminalisation of the practice and the impact on the mechanism of judicial co-operation in criminal matters as regards mutual recognition of judicial decisions.
\end{abstract}

\section{Key words}

Child grooming; online child grooming; child pornography; solicitation of children for sexual purposes; the Convention on the protection of children against sexual exploitation and sexual abuse; the Directive 2011/92/EU on combating the sexual abuse and sexual exploitation of children and child pornography.

\section{Introduction}

The spread of the internet brings a higher possibility of abuse of children by sex offenders (Davidson \& Gottschalk, 2011, p. 92). In the past only family members or close friends had private access to children (Clough, 
2015, p. 332). In these days, internet communication and social networks enable virtually anyone to communicate privately with children directly in their homes. In some cases, adults use the internet with a specific intention of grooming a child (children) as a preparatory step to committing sexual act(s). Such acts can either be perpetrated in the physical world or in the virtual world, by use of information technologies to encourage a child to engage remotely in illegal or harmful sexual or other acts (Carr, 2010, p. 273). Many parents are of the opinion that children are safe in their own homes. There is no stranger at home and therefore there is no risk for children playing at home. The parents underestimate the negative power of the internet. Today children often prefer computers, tablets, smartphones to classic forms of leisure activities. Once connected, they can become a target for potential groomers. Almost all social networks have the possibility for users to create fake online profiles. One can discuss whether or not children, growing up with such access to the virtual world, are able to distinguish the potential danger.

The objective of this paper is the assessment of online child grooming and its criminalisation in Europe, including the assessment of its impact on the procedural aspect of criminal law. The article is not focused on figures or the number of abused children. Rather, it is focused on common European approach towards its criminalisation and its impact on the mechanism of judicial co-operation in criminal matters as regards mutual recognition of judicial decisions. ${ }^{1}$

\section{Grooming: A Strategy Towards Sexual Abuse of Children}

\section{1. "Traditional" Grooming}

Grooming is a strategy used by many paedophiles. It is a seductive process with the objective of befriending a child and subsequently preparing the child for sexual abuse. The process can take many days or even years. It can allow paedophiles to sexually abuse children, but to remain undetected. A potential abuser can be a "well known" person, for example, neighbour, teacher, trainer or even father or mother of a friend.

Worldwide there is no binding understanding of definition of grooming. The literature contains any number of definitions, from simple or exhaustive. Davidson and Gottschalk argue that grooming is the process by which a person befriends a child with the intention of committing sexual abuse (Davidson \& Gottschalk, 2011, p. 80). Ost argues that grooming can be conceived as a predatory act committed in order to facilitate sexual abuse (Ost, 2009 , p. 92). Dean defines grooming as friendly, flattering or supportive actions intended to win the trust of a child, as a first step toward the sexual abuse of

1 The paper was elaborated as a part of the research project VEGA No. 1/0004/20 'Implementation of Mutual Recognition of Judicial Decisions in Criminal Matters into the Legal Order of the Slovak Republic' [Slovak: Zavedenie vzájomného uznávania justičných rozhodnutí v trestných veciach do právneho poriadku Slovenskej republiky]. 
that child. He adds, importantly, that sexual predators also use the grooming process to isolate the child from people who might protect him or her (Dean, 2007, p. 65). Grooming consists of paedophiles establishing a trust relationship with a minor to subsequently meet for sexual abuse (Casey, 2011, p. 166).

It is beyond the scope of this paper to engage in an in-depth analysis of its medical understanding of paedophilia as a psychiatric condition. Briefly, to fall within the diagnosis of paedophilia (302.2), according to the American Psychiatric Association each of the following three diagnostic criteria must be fulfilled ("American Psychiatric Association", 2013):

A. Over a period of at least 6 months, recurrent, intense sexually arousing fantasies, sexual urges, or behaviours involving sexual activity with a prepubescent child or children (generally age 13 years or younger),

B. The individual has acted on these urges, or the sexual urges or fantasies cause marked distress or interpersonal difficulty,

C. The person is at least age 16 years and at least 5 years older than the child or children in Criterion A.

\section{2. "Online" Grooming}

\subsubsection{Grooming Procedure}

Social networking sites are popular among youth and adults alike. Children using the internet can innocently make contact with anyone, and be contacted by anyone, while online. In principle, two scenarios are possible. First, the paedophile knows the child before contacting him or her. The grooming activities of the paedophile are focused on a known child which he or she wants to "catch". The paedophile does not use a real online profile. Rather, he or she develops a fake profile with fake information. Second, the paedophile does not know the child before contacting him or her. The paedophile browses available online profiles and selects his or her "target(s)". Of course, in this scenario the paedophile also does not have a legitimate online profile based on real information.

Creating a fake profile online is simple. Anyone can make the fake email online registration needed to registration on social networks and then create a fake account. If verification by mobile phone is needed, one can buy second mobile phone and use its number for registration purposes without the user being known. Moreover, it is possible to change or even hide the Media Access Control (MAC) address of a personal computer. In addition, it is possible to change or even hide IP address (Internet Protocol) using, for example, a VPN service (Virtual Private Network), browser or proxy server.

Adult abusers that enter child-orientated chat rooms will disguise their real age and gender in order to more successfully groom and abuse children. These people have considered this issue and have made the decision to create a false image of themselves in the belief that, by appearing as a child or as an adolescent and perhaps appearing as a female rather than a male, they increase their chances of success. Online abusers have been known to create completely fictitious profiles for themselves in preparation for going online and 
communicating with children. These profiles consist of a host of bogus names, false ages, dates of birth, names and ages of spurious siblings and parents, fake addresses and "home-town" locations and, to complete the job, a photograph of a child matching the false physical description (Powell, 2007, p. 117).

Online chat rooms, messaging and other internet possibilities of communication become tools of sexual predators for grooming their victims.

The children most at risk of being groomed are usually between the ages of ten and sixteen. This can be explained by the fact that younger children do not, or at least not as often, communicate through the internet. Furthermore, girls have a higher risk of being groomed than boys, but boys also form a substantial group of victims (Kool, 2011, p. 50). Young people from a socially and emotionally poor background have a higher risk of being groomed, which should be viewed in relation to the degree of parental supervision of the child's online communication as well as the child's need for adult attention.

Some groomers have up to 200 young people on their online "friends" lists who are at different stages of the grooming process at any given time (Webster et al., 2010, p. 13). O'Connell identifies five stages to grooming (O'Connell, 2003, pp. 6-8), (i) the friendship-forming stage, (ii) the relationship-forming stage, (iii) the risk assessment stage, (iv) the exclusivity stage and $(v)$ the sexual stage.

\subsubsection{Definition of Online Groomer}

In the literature, the online groomer is defined as someone who has initiated online contact with a child with the intention of establishing a sexual relationship involving cyber-sex or sex with physical contact (Davidson et al., 2011 , p. 8). In the opinion of Sanderson, paedophiles are sexual predators dressed up as nice men, or wolves in sheep's clothing. They have a vested interest in being seen as normal and nice, so that they can blend into the background and avoid suspicion (Sanderson, 2004, p. 167). The online groomer can create a profile of anybody, for example, a kind adolescent, a smart student, a successful sport player, or a grown-up university graduate at the beginning of professional career. There are almost unlimited possibilities for the groomer in the online world. At first look it is not possible, in the majority of cases, to notice that a person contacting a child has a fake profile. Groomers know how to communicate with and as children. They know their slang, they use their common phrases. Naturally, they proceed patiently. The majority of groomers have contact with a series of children simultaneously.

It should be noted that although less common than men, female sexual groomers follow many of the same grooming patterns.

\section{Criminalisation of Behaviour Related to Child Sexual Grooming in European States at National Level: Early Beginnings}

In the European States, a number of existing offences can apply to behaviour related to sexual exploitation of children or child pornography. Moreover, there are also applicable offences as regards online grooming. Two decades ago this was not the case. In the United Kingdom, grooming was made 
an offence in 2003. Previous to this time, there had been a number of worrying cases where adult men met young children after contacting them initially by email or through caps chatrooms (Bainbridge, 2007, p. 475). The United Kingdom was one of the first European States to initiate strong legislation making it illegal to contact and groom children with the intent of committing a sexual offence. This new offence category was introduced in the Sexual Offences Act 2003 (child grooming is proscribed by Sections 14 and 15).

As pointed out by Ost, a question is why the creation of a specific offence relating to grooming was thought to be a better step forward than simply utilising the law of attempt. Why not simply arrest an individual who intends to commit a sexual offence against a child and charge him or her with attempt to commit that particular offence? In order to make the legal argument in this case, it is necessary to prove that an individual has gone beyond committing merely preparatory acts to satisfy the necessary elements of the offence of attempt. The creation of the offence of meeting a child following sexual grooming enables the police to charge an individual in circumstances where, previously, there may have been insufficient evidence to establish that the individual had committed more than preparatory acts to the relevant offence under the existing law (Ost, 2009, pp. 70-71).

The introduction of this offence demonstrated the increased societal awareness of the way in which grooming can occur via the internet (Ost, 2009, p. 70). During the following years several European States, for example Norway and the Netherlands, followed the lead of the United Kingdom in legislating against online grooming behaviour. In 2007 Norway adopted provisions on child grooming in the General Civil Penal Code, adding Section 201a which addressed the issue. Under this law any person is liable, who has agreed to a meeting with a child who is under 16 years of age, and who, with the intention of committing a sexual act, has been observed arriving at the meeting place.

The Netherlands criminalised grooming in 2010. Under the Dutch Criminal Code (Article 248e) any person who, by means of a computerised action or using a communication service, suggests a meeting with a person about whom they know or should reasonably have suspected had not reached the age of 16, with the intention of committing indecent acts with that person or producing an image of a sexual act involving that person, shall be indicted (Kool, 2011, p. 61).

Discussions have begun at the European level on the need for a Europewide approach to this issue. It was clear that online grooming must inevitably be regulated by legislation as criminal offence in whole Europe.

\section{European Responses at Trans-national Level}

As seen, in 2000's several European States had already made online child grooming a criminal offence through national legislative measures. By the end of the decade, through the EU, the majority of European States faced a new requirement to stipulate online child grooming as criminal offence at national level. For these purposes two crucial legislative instruments were 
introduced. First, the Council of Europe in 2007 adopted the Convention on the Protection of Children against Sexual Exploitation and Sexual Abuse. Second, the European Union in 2011 adopted the Directive 2011/93/EU on combating the sexual abuse and sexual exploitation of children and child pornography. These legislative instruments directly pointed to the harmonization of national legislation on online child grooming in European States.

\subsection{Council of Europe Response: Convention on the Protection of Children Against Sexual Exploitation and Sexual Abuse}

At the European, level the need for harmonization of online child grooming by legislation appeared for the first time within the Council of Europe. In 2007, the Council adopted the Convention on the Protection of Children against Sexual Exploitation and Sexual Abuse (hereinafter the "Convention"). It was open for signature by the Member States Council of Europe, its non-member States which participated in its elaboration and by the European Union, and for accession by other non-member States in Lanzarote, Spain on $25^{\text {th }}$ October 2007. As regards Member States, all have accessed it by signature. Moreover, almost all of them, excluding Armenia and Ireland, have ratified it and therefore in such States it has entered into force.

The Convention has three purposes: "( $i$ ) to prevent and combat sexual exploitation and sexual abuse of children, (ii) to protect the rights of child victims of sexual exploitation and sexual abuse and (iii) to promote national and international co-operation against sexual exploitation and sexual abuse of children" (Article 1 of the Convention).

The Convention regulates child exploitation and more specifically online child grooming. At the European level it introduced a new offence, solicitation of children for sexual purposes, which prior this Convention had never been anchored by international legislative instruments. According to the Convention each contracting State shall take the necessary legislative or other measures to criminalise the intentional proposal, through information and communication technologies, of an adult to meet a child who has not reached the needed age (for purposes of the Convention, each contracting State shall decide the age below which it is prohibited to engage in sexual activities with a child), for the purpose of committing of the sexual abuse or producing child pornography, against him or her, where this proposal has been followed by material acts leading to such a meeting (Article 23 of the Convention). The Convention does not focus on a meeting. Rather, it focuses on acts leading to such a meeting. Indeed, for purposes of the criminal liability, there is no need to catch the offender at the time of meeting with the child. Acts leading to such a meeting, for example, travelling by vehicle to meet a child, establishes criminal liability.

The negotiators of the Convention felt that simply sexual chatting with a child, albeit as part of the preparation of the child for the specified offences, was insufficient in itself to incur criminal liability. A further element was needed. The Convention therefore requires States to criminalise the intentional proposal of an adult to meet a child. Thus, the relationship-forming contacts 
must be followed by a proposal to meet the child. This then is understood as an intentionally committed offence. The purpose of the proposal of an adult shall be established before criminal liability is incurred. The offence can only be committed using of information and communication technologies, for example, by computer, smartphone, or tablet (Council of Europe, 2007, p. 3).

Other forms of grooming through real contacts or non-electronic communication are outside the scope of the above cited provision of the Convention. In view of the particular danger inherent in the use of such technologies due to the difficulty of monitoring them the negotiators of the Convention wished to focus the provision exclusively on the most dangerous method of grooming children which is through the internet and by using mobile phones to which even very young children increasingly have access.

\subsection{European Union Response: Directive 2011/93/EU on Combating the Sexual Abuse and Sexual Exploitation of Children and Child Pornography}

The European Union explicitly recognised protection of children's rights in its Charter of Fundamental Rights. A legal framework for combating sexual abuse and sexual exploitation of children existed through Directive 2011/93/EU on the sexual abuse and sexual exploitation of children and child pornography. The European Union adopted the Joint Action 97/154/JHA concerning action to combat trafficking in human beings and sexual exploitation of children, which was later repealed and replaced by the Framework Decision 2004/68/JHA on combating the sexual exploitation of children and child pornography. However, these legislative instruments introduced a minimum of approximation for the Member States of the European Union legislation to criminalise the most serious forms of child sexual abuse and exploitation. Although the requirements addressed to States were generally implemented, there were a number of shortcomings. For example, they approximated national legislation only on a limited number of offences and naturally, they did not address newer forms of abuse and exploitation using information technologies.

Since the ratification of the Treaty of Lisbon in 2009, the European Union legislators enjoy greater power to adopt legislation on criminal enforcement and sanctions, which has led to policy making that combats child pornography on the internet. The European Union then turned its attention to specific legislation focused on online child grooming (Davidson, 2011, p. 16).

Directive 2011/93/EU on combating the sexual abuse and sexual exploitation of children and child pornography (hereinafter the "Directive") was adopted in 2011, a few years after the Convention on the Protection of Children Against Sexual Exploitation and Sexual Abuse was adopted within the Council of Europe. The Directive establishes minimum rules addressed to the Member States of the European Union concerning " $(i)$ the definition of criminal offences and sanctions in the area of sexual abuse and sexual exploitation of children, child pornography and solicitation of children for sexual purposes; (ii) it also introduces also provisions to strengthen the 
prevention of those crimes and the protection of the victims thereof" (Article 1 of the Directive).

The Directive introduced an additional European approach towards criminalisation of online child grooming (Klimek, 2012, pp. 141-151). There is an opinion that The Directive has an uncharacteristically aggressive U.S.-style call for action (Kendall \& Funk, 2011, p. 141), including the requirement addressed to European Union Member States to criminalise grooming-related offences, which requirement is explicitly premised by the wording of the Directive.

As far as online child grooming is concerned, the Directive introduces at the European Union level a new offence, solicitation of children for sexual purposes. Under the Directive the Member States of the European Union shall take the necessary measures to ensure that intentional solicitation of children for sexual purposes by means of information and communication technology is punishable (Article 6 of the Directive).

The Directive stipulates that the Member States of the European Union shall take the necessary measures to ensure that it is a legally punishable offence for an adult, by means of information and communication technology, to meet a child who has not reached the age of sexual consent, for the purpose of engaging in sexual activities with a child, or/and production of child pornography, where material acts lead to such a meeting (for purposes of the Directive the term child shall mean any person below the age of 18 years and the term age of sexual consent shall mean the age below which, in accordance with national law of the Member State(s) of the European Union). Moreover, the Member States shall take the necessary measures to ensure that an attempt, by means of information and communication technology, to commit acquisition or possession of child pornography, or/and knowingly obtaining access by an adult soliciting a child who has not reached the age of sexual consent to provide child pornography depicting that child is also punishable. Moreover, inciting or aiding and abetting to commit any of mentioned offences is also punishable.

Since the directives of the European Union do not entail a direct effect on the national laws of the Member States of the European Union, their implementation by the member states is needed. As regards Directive 2011/93/EU, the Member States shall bring into force national implementation measures necessary to comply with this Directive by $18^{\text {th }}$ December 2013 . In fulfilment of this requirement the majority of the Member States amended their national laws, in particular Criminal Codes and also related non-criminal laws regulating protection of youth and/or children. For example, Luxembourg established the Act on the Protection of Young People of 1992, Hungary the Act on the Protection of Children of 1997 and the Slovak Republic the Act on the Social-legal Protection of Children of 2005.

Two reports evaluating the Directive have been published by the European Commission. The first report evaluates the Directive as a whole (European Commission, 2016a), while the second report evaluates specifically the measures introduced with regard to websites containing or disseminating child pornography (European Commission, 2016b). The European Commission 
considers the Directive as a comprehensive legislative framework which has led to substantive progress in the Member States in amending criminal codes, criminal procedures and sectorial legislation, streamlining procedures, setting up or improving co-operation schemes and improving the co-ordination at national level. The Commission acknowledged the major efforts made by the Member States to implement the requirements of the Directive. As regards online child grooming, i.e. the criminal offence solicitation of children for sexual purposes, in principle, most Member States have in place legislation that implemented relevant provisions of the Directive.

\subsection{Impact on Mutual Recognition of Judicial Decisions in Criminal Matters}

The European approach towards online child grooming, i.e. the criminal offence solicitation of children for sexual purposes, also has a procedural dimension. It has impact on mutual recognition procedures in criminal matters.

Much has been written and published on the topic of mutual recognition as a general concept of the European Union (Armstrong, 2002; Schmidt, 2008; Kerber \& van den Bergh, 2012; Janssens, 2013). As regards criminal matters, the mechanism of mutual recognition permits judicial decisions to move freely from one European State to another. It is understood as a key element of judicial co-operation in criminal matters. Its implementation became one of the main areas of European Union activity regarding criminal justice (Klimek, 2017). Within the European Union legislative instruments addressed to its Member States to implement criminal dimension of mutual recognition in Europe have been adopted. Some of these instruments place the criminal offence of solicitation of children for sexual purposes on the so-called "list of 32 mutual recognition offences" (also known as "32 MR offences", "list of 32 offences", or "double criminality list") as a part of the category entitled sexual exploitation of children and child pornography.

The double criminality requirement and its verification has been, for many decades, a general principle of international law in the European context with regard to co-operation in criminal matters. Recent evolution in this cooperation reveals a tendency to abandon the double criminality requirement in European Union criminal law. The Member States of the European Union looked into alternatives and the possibility of limiting the use of the double criminality requirement (Vermeulen, De Bondt \& van Damme, 2010, pp. 63 and 64). Since one of the objectives of the concept of mutual recognition in criminal matters is the acceptance of foreign decisions, they found the solution - partial abolition of the double criminality requirement.

Within co-operation in criminal matters between Member States of the European Union the principle of mutual recognition and the presumption of the mutual trust caused the abolition of the double criminality requirement for selected categories of criminal offences. The verification of double criminality is abolished for 32 mutual recognition offences (in case of mutual recognition of financial penalties 39 offences. Such partial removal of the double 
criminality requirement (i.e. no double criminality requirement for listed offences) can be observed in these mutual recognition instruments:

- the Framework Decision 2002/584/JHA on the European arrest warrant and the surrender procedures between Member States (Article 2(2));

- the Framework Decision 2008/909/JHA on the mutual recognition of custodial sentences and deprivation of liberty (Article 7(1));

- the Framework Decision 2008/947/JHA on mutual recognition of probation measures and alternative sanctions (Article 10(1));

- the Framework Decision 2005/214/JHA on the mutual recognition of financial penalties (Article 5(1); in this framework decision the list is extended to 39 offences);

- the Framework Decision 2006/783/JHA on the mutual recognition of confiscation orders (Article 5(1)); as from $19^{\text {th }}$ December 2020 this Framework Decision shall be replaced and repealed by the Regulation (EU) 2018/1805 on the mutual recognition of freezing orders and confiscation orders (list of 32 mutual recognition offences is placed in Article 3 (1));

- the Framework Decision 2009/829/JHA on the European supervision order (Article 14(1)); and

- the Directive 2014/41/EU on the European investigation order (Annex D).

Under the abovementioned measures, on the one hand, the Member

State recognising and executing a foreign decision may invoke the double criminality requirement. It is an optional step and the double criminality check is not mandatory in the procedure. The decision rests on the competent authority of the executing State. On the other hand, the double criminality shall not be checked in the Member State recognising and executing foreign decision.

Such a revolutionary step was been taken for the first time by the Framework Decision 2002/584/JHA on the European arrest warrant and the surrender procedures between Member States (Article 2(2)). In the surrender procedure introduced by this Framework Decision the double criminality was softened. It is not required for the list of 32 offences, i.e. mutual recognition offences. In practice the abolition of the verification of double criminality is understood as a key feature of the European arrest warrant. As seen, further procedural impact can be observed, for example, in the mechanism based on the Framework Decision 2008/909/JHA on the mutual recognition of custodial sentences and deprivation of liberty (Article 7(1)). Similarly, as regards the European arrest warrant, the double criminality of 32 categories of offences is not checked by the judicial authority of the executing Member State. Such a rule contains all abovementioned mutual recognition legislative instruments in criminal matters. The result is simplification of co-operation in criminal matters within the European Union. Indeed, if, for example, the European arrest warrant is issued within criminal proceedings for online solicitation of children for sexual purposes, the verification of double criminality is not needed. 


\section{Conclusion}

In the European States a number of existing offences can apply to behaviour related to sexual exploitation of children or child pornography. Moreover, there are also applicable offences as regards online grooming.

In 2000's several European States had already made online child grooming a criminal offence through national legislative measures. Later, the majority of European States enacted a new requirement to stipulate online child grooming as criminal offence at national level. For these purposes two crucial legislative instruments have been introduced. First, within the Council of Europe in 2007 was adopted the Convention on the Protection of Children against Sexual Exploitation and Sexual Abuse. Second, the European Union in 2011 adopted Directive 2011/93/EU on combating the sexual abuse and sexual exploitation of children and child pornography. While the Convention can be considered the first international document in this field in European context, the Directive introduced an additional European approach towards criminalisation of online child grooming.

The European approach towards online child grooming, i.e. the criminal offence solicitation of children for sexual purposes, has also procedural dimension. It has impact on mutual recognition procedures in criminal matters. Within co-operation in criminal matters between its Member States the principle of mutual recognition and the presumption of the mutual trust caused the abolition of the double criminality requirement for selected categories of criminal offences. In case mutual recognition measures in criminal matters the verification of double criminality is abolished for 32 mutual recognition offences. Some of these instruments invoke the criminal offence solicitation of children for sexual purposes on the so-called "list of 32 mutual recognition offences". For example, the European arrest warrant is issued within criminal proceedings for online solicitation of children for sexual purposes, the verification of double criminality is not needed. 


\section{References}

American Psychiatric Association. 2013. Diagnostic and Statistical Manual of Mental Disorders. $5^{\text {th }}$ edition (DSM-5). Washington: American Psychiatric Association

Armstrong, K. 2002. Mutual Recognition. In Barnard, C. \& Scott, J. (eds.) The Law of the Single European Market: Unpacking the Premises. Oxford, Portland: Hart Publishing, pp. 225-268

Bainbridge, D. 2007. Introduction to Information Technology Law. $6^{\text {th }}$ edition. Essex: Pearson Education

Carr, J. 2010. The Internet Dimension of Sexual Violence Against Children. In Protecting Children from Sexual Violence: A Comprehensive Approach. Strasbourg: Council of Europe Publishing

Casey, E. 2011. Digital Evidence and Computer Crime: Forensic Science, Computers and the Internet. Waltham, San Diego,London: Academic Press

Clough, J. 2015. Principles of Cybercrime. $2^{\text {nd }}$ edition. New York: Cambridge University Press

Council of Europe. 2007. Explanatory Memorandum to the Convention on the Protection of Children against Sexual Exploitation and Sexual Abuse, Lanzarote, $25^{\text {th }} \quad$ October 2007. Retrieved from https://rm.coe.int/16800d3832

Davidson, J. - Gottschalk, P. 2011. Internet Child Abuse: Current Research and Policy. Abingdon, New York: Routlegde

Davidson, J., Grove-Hills, J.,Bifulco, A. et al. 2011. Online Abuse: Literature Review and Policy Context. Review prepared for the European Commission Safer Internet Plus. European Online Grooming Project. Retrieved from http://citeseerx.ist.psu.edu/viewdoc/download?doi=10.1.1.473.1618\& rep=rep $1 \&$ type $=$ pdf

Dean, S. 2007. Sexual Predators: How to Recognize Them on the Internet and on the Street: How to Keep Your Kids Away. Los Angeles, Aberdeen: Silver Lake Publishing

European Commission. 2016a. Report assessing the extent to which the Member States have taken the necessary measures in order to comply with Directive 2011/93/EU of $13^{\text {th }}$ December 2011 on combating the sexual abuse and sexual exploitation of children and child pornography, $\operatorname{COM}(2016) 871$ final. Retrieved from https://eurlex.europa.eu/legal-content/EN/TXT/?uri=CELEX\%3A52016DC087

European Commission. 2016b. Report assessing the implementation of the measures referred to in Article 25 of Directive 2011/93/EU of $13^{\text {th }}$ December 2011 on combating the sexual abuse and sexual exploitation of children and child pornography, $\operatorname{COM}(2016) 872$ final. Retrieved from https://eur-lex.europa.eu/legalcontent/EN/TXT/?uri=CELEX\%3A52016DC087

Janssens, Ch. 2013. The Principle of Mutual Recognition in EU Law. New York: Oxford University Press 
Kendall, V. and Funk, M. 2011. Child Exploitation and Trafficking: Examining the Global Challenges and U.S. Responses. Plymouth: Rowman \& Littlefield

Kerber, W. and Van den Bergh, R. 2012. "Mutual Recognition in the Global Trade Regime: Lessons from the EU Experience." In Lianos, I. and Odudu, O. (eds.) Regulating Trade in Services in the EU and the WTO: Trust, Distrust and Economic Integration. New York: Cambridge University Press, pp. 121-146

Klimek, L. 2012. "Solicitation of Children for Sexual Purposes: The New Offence in the EU (Under the Directive 2011/92/EU)." In International and Comparative Law Review 12: 141-151

Klimek, L. 2017. Mutual Recognition of Judicial Decisions in European Criminal Law. Cham, Switzerland: Springer International Publishing

Kool, R. 2011. "Prevention by All Means?: A Legal Comparison of the Criminalization of Online Grooming and its Enforcement." In Utrecht Law Review 7: 46-69

O'Connell, R. 2003. A Typology of Child Cybersexplotation and Online Grooming Practices. Preston: Cyberspace Research Unit

Ost, S. 2009. Child Pornography and Sexual Grooming: Legal and Societal Responses. New York: Cambridge University Press

Powell, A. 2007. Paedophiles, Child Abuse and the Internet: A Practical Guide to Identification, Action and Prevention. Oxford: Radcliffe Publishing

Sanderson, Ch. 2004. The Seduction of Children: Empowering Parents and Teachers to Protect Children from Child Sexual Abuse. London, Philadelphia: Jessica Kingsley Publishers

Schmidt, S. 2008. Mutual Recognition as a New Mode of Governance. Oxford, New York: Routledge

Vermeulen, G. , De Bondt, W. and van Damme, Y. 2010. EU Cross-Border Gathering and Use of Evidence in Criminal Matters: Towards Mutual Recognition of Investigative Measures and Free Movement of Evidence? Antwerpen: Maklu

Webster, S., Davidson, J., Bifulco, A. et al., 2010. Scoping Report of the European Online Grooming Project. Prepared for and co-funded by the European Commission Safer Internet Plus Programme. Retrieved from https://natcen.ac.uk/media/22517/european-online-groomingprojectscopingreport.pdf 
